\title{
THE SOCIAL FIELD OF SMART VILLAGES CONCEPT: THE CASE OF PERIPHERAL REGION - LUBLIN PROVINCE IN POLAND
}

Danuta GUZAL-DEC ${ }^{1}$, Phd, Professor; Magdalena ZWOLINSKA-LIGAJ ${ }^{2}$, PhD

${ }_{1,2}$ Pope John Paul II State School of Higher Education in Biala Podlaska, Faculty of Economics and Technical Sciences

\begin{abstract}
Lagging regions are characterised by coupling of numerous barriers to their development including the ones in the dimension of human and social capital. The concept of smart villages identifies the modes of overcoming these barriers. The aim of the paper was to operationalise and to evaluate social potential of smart village in case of lagging region (Lublin Province, Poland). A quantitative approach was applied during the research. The work uses a descriptive method in the theoretical part and statistical methods in the empirical part. In the light of the statistical analyses carried out in the research process, there has been no indication of a higher potential of rural-urban communes in comparison to rural units. The potential of social smart is strongly dispersed. A positive impact of larger urban centres in the region on the rural potential cannot be identified. However, certain concentrations can be distinguished in the framework of selected Local Action Groups (LAGs) that operate in Lublin Province. Since the peripheral regions are in particular sparsely populated by the creative class, and it is difficult to attract the creative class of people, it should be noted that investing in and promoting smart people becomes necessary catalysts for the implementation of smart villages concept. It is therefore essential to strengthen the connection between the regional and sub-regional scientific centres and commune self-governments. Fostering the activity of LAGs operating in the Community-Led Local Development (CLLD) approach in the framework of LEADER programme seems to be the desired direction of the support for endogenous potential of rural territorial units enabling the smart villages concept implementation.
\end{abstract}

Key words: smart city, smart people/community, smart village, lagging regions.

JEL code: 018

\section{Introduction}

In the era of consumer society, the quality of life constitutes an essential factor contributing to the territorial competitiveness. Territorial competitiveness, more increasingly, is built on the qualitative criteria, and not on the quantitative growth factor. The aspect of knowledge is also important. On the grounds of territorial competitiveness theory, the concept of regional smart specialisation and a new urban development trend, i.e. smart city was shaped, while the concept of smart villages is currently being formed. With regard to the European Union (EU), new development challenges form an integral part of the Europe 2020 Strategy for smart, sustainable and inclusive growth. As part of the EU policy, smart growth is being used in the context of knowledge and covers the policy of innovation, education and research. In this regard, it remains a particular challenge to establish the fundamentals for smart growth through the implementation of the concept of smart villages in the peripheral rural regions.

The peripherality, despite the socio-economic development, does not disappear. What is more, among the units (regions) classified as peripheral, some groups of outlier territorial units can be distinguished (lagging regions) (Olechnicka, Smetkowski, 2007: p. 1) into two categories: of extremely high indicators in different peripheral dimensions and of low dynamics of improvement of these indicators.

Lagging regions accumulate the socio-economic barriers to development. In economic terms, these include: low level of GDP per capita, low capital expenditure on public services and limited access to them, and/or their low quality. In demographic terms, peripherality manifests itself in depopulation and progressive aging of the local community, the outflow of young people, low and decreasing density of population. Peripherality in case of lagging regions is also characterized by the deteriorating quality of human capital resulting from the outflow of the best educated and the

${ }^{1}$ Corresponding author. .Tel.:: +48603867576; fax:+48833449950.E-mail address: danuta_guzal-dec@wp.pl .ORCID:0000-0002-2143-1649 296 ${ }^{2}$ Corresponding author. Tel.: +48606374521; fax: +48833449950. E-mail address: m.zwolinska-ligaj@dydaktyka.pswbp.pl ORCID:0000-00016770-709) 
most active entities, and in the context of social capital - the low level of cooperation and bridging of social capital, the deprivation of local elites, and limited competences of local authorities (Nurzynska, 2016: pp.135-136).

In the peripheral regions, we observe a number of feedback loops between the indicated development barriers causing the formation of the so-called vicious circles of development (Krueger, 1993). For example, the phenomenon of depopulation of peripheral border regions also brings consequences for social capital. Aging processes may weaken social self-organization, innovativeness of attitudes, decreasing number of local community leaders. The ability to see and use the opportunities to overcome peripheral barriers depends on the activity and innovation of the community and the attitudes of local leaders. In the peripheral regions, we often encounter the problem of lack of real local leaders and the passivity of local communities (Miszczuk, 2013).

The group of lagging regions includes the provinces of the Eastern Poland Macroregion - among others Lublin Province constituting the research area. The province is located at the eastern border of the EU. In terms of economic peripherality, the region remains in the group of the leastdeveloped regions in the EU in terms of GDP per capita expressed according to the purchasing power parity (with GDP below $50 \%$ of the EU average) (Eurostat 2016).

In the light of barrier characteristics to development of peripheral regions, the concept of smart villages seems to be attractive in overcoming these barriers. This is a new concept requiring practical embedding in local conditions and operationalisation.

The aim of the paper was to operationalise and to evaluate social potential of smart village in case of lagging region.

The following stages of the study were adopted:

- systematising the achievements in the field of theoretical foundations of the smart villages concept, including the social identification of its dimension,

- operationalisation of the social dimension of the smart villages concept (based on data available in Polish mass statistics),

- characteristics of rural and urban-rural communes of Lublin Province - lagging region in Poland and the European Union in the aspect of smart social potential.

The following hypotheses were formulated to address the research problem.

1) Urban-rural units show a higher level of the social dimension of smart development compared to rural communes. Due to the level of the social dimension of smart development the structure of urban-rural communes differs from the structure of rural communes.

2) Communes situated in the close vicinity of the region's main medium-sized and large urban centres (capital of the region) demonstrate a higher level of the indicator of the social dimension of smart development compared to communes which are peripherally located within the region; Communes with a higher level of the social indicator of the smart dimension are concentrated (presence of clusters) around the medium-sized and large urban centres in the region.

In the theoretical part of the paper, descriptive method and empirical statistical method were used. The statistical methods applied are as follows: zero unitarisation method, similarity of structures test, Mann-Whitney $U$ test. 


\section{Research results and discussions \\ 1. The concept of smart city as the base of formulating smart villages concept through the lens of social field}

The concept of smart city is commonly found in the academic literature along with other related terms such as: smart community, smart city, information city, creative city, learning city, knowledge city (Gil-Garcia, 2015). The term was first used in the 1990s. The dynamic development of cities and their surroundings, including the technological environment in the context of the dynamising process of globalisation and the growing competition between territories, has influenced the rapid development of the concept of a smart city. This was also supported by the political support of global institutions, including the United Nations, the European Union and the OECD (Cocchia, 2014).

The smart city concept is the result of three trends in urban research, i.e. digital city, green city and knowledge city (Chourabi et al., 2012). Smart city is a multidimensional concept. Originally, the narrow definition was focused around information technology. Nam and Pardo presented the model of an intelligent city with three dimensions: technology, people and institutions (Nam, Pardo, 2011). Lombardi et al. (2012) distinguished six areas of smart city concept implementation. These include: economy, people, management, mobility, environment and quality of life.

In a broad definitional approach, smart city is perceived as a new paradigm in urban development (Neirotti et al., 2014), where human and social capital, education and the natural environment play an important role in the concept (Lombardi et al., 2012). An example of a broad definitional approach to a smart city through the prism of smart people is the definition of Komninos (2006: p.13): who defined them as "territories that bring innovation systems and ICTs within the same locality, combining the creativity of talented individuals that make up the population of the city, institutions that enhance learning and innovation, and digital innovation spaces facilitating innovation and knowledge management".

Literature review allows to notice that in addition to information technology, the social factor is a basic dimension/ area in the smart city concept. Quality of life, human capital (also in the context of local government competence) and social capital constantly appear in the proposals for the operationalisation of the concept (see the work of Mahizhnan, 1999, Giffinnger et al., 2007, Eger, 2009; Thuzar, 2011; Chourabi et al. 2012).

According to Bartlett (2005), intellectual capital and social capital are "indispensable endowment" to smart cities. "Smart city is about a mix of education/training, culture/arts, and business/commerce". The smart people concept comprises various factors like: open-mindedness, affinity to life-long learning, social and ethnic plurality, flexibility, creativity, cosmopolitanism or, and participation in public life Hollands 2008). The label smart city points to "clever solutions by creative people" (Monfaredzadeh, Krueger, 2015). Initiatives under smart cities concept have an impact on the quality of life of citizens and aim to foster more informed, educated, and participatory citizens (Chourabi at al., 2012).

People are smart in terms of their skill and educational levels, as well as the quality of social interaction in terms of integration and public life and their ability to open to the "outside" world. Towards more progressive smart cities, cities should start with people from the human capital side, rather than blindly believing that IT itself can automatically transform and improve cities (Shapiro, 2006, Hollands 2008).

${ }^{1}$ Corresponding author. .Tel.:: +48603867576; fax:+ 48833449950.E-mail address: danuta_guzal-dec@wp.pl .ORCID:0000-0002-2143-1649298 ${ }^{2}$ Corresponding author. Tel.: +48606374521; fax: +48833449950. E-mail address: m.zwolinska-ligaj@dydaktyka.pswbp.pl ORCID:0000-0001- 
People are the protagonists of a smart city, who shape it through continuous interactions (Albino et al., 2015: p.9). For this reason, creativity is recognized as a key driver of smart city, and thus education, learning, and knowledge have central roles in a smart city (Thuzar, 2011).

Another category connected with social field of smart city concept is community (Nam, Pardo, 2011). The importance of this factor emulates the concept of smart communities where members and institutions work in partnership to transform their environment (Berardi, 2013). This means that the community of a smart city needs to feel the desire to participate and promote a (smart) growth (Albino et al., 2015: p. 9). According to Monzon (2015: p. 22), the main challenges to face in the smart people action field are improving social cohesion and quality of life.

In view of the need to implement the assumptions of the Europe 2020 Strategy, the concept of smart growth in rural areas, the concept of smart villages emerged in the European Union's development policy. The emerging concept refers to rural areas and communities that use their strengths and resources and take advantage of opportunities. In smart villages, traditional and new networks and services are enhanced by means of digital technologies, telecommunications, innovation and better use of knowledge for the benefit of residents and enterprises. The concept of smart villages does not offer a universal solution. It is territorially embedded, based on the needs and potentials of a given territory and guided by the strategy, supported by new or existing territorial development strategies. The concept of smart villages refers to settlements in rural areas as well as rural landscapes (EU Action for ..., 2017).

Technology is important in the concept of smart villages, as are investments in infrastructure, business development, human capital, potential and building a civic society. Good management and involvement of citizens is also important. The concept of smart villages draws attention to the abilities of using e-skills, access to e-health and other basic services, innovative solutions in the field of environmental protection, the use of circular economy in relation to agricultural waste, promotion of local products supported by technology and ICT, implementation and reaping the full benefits of smart specialisations in agri-food projects, tourism, cultural activities, etc. (EU Action for ..., 2017).

In the European Union, the implementation of the smart villages concept also results directly from the Cork Declaration guidelines for the development of rural areas. One of the key recommendations of the Cork 2.0 Declaration (2016) is the need to work across policy fields to promote rural prosperity. As a response on this declaration the Smart Village initiative was launched by European Commission. "It aims at improving the implementation of EU policies in rural areas. To do this, digital technologies, innovations and the better use of knowledge will be enhanced to benefit rural populations and businesses" (Innovation and digitization..., 2017; Villages and small..., 2017).

The smart city concept in the dimension of smart people and the "being smarter people" process is closely related to the concept of inclusiveness development postulated in the Europe 2020 Strategy. Promoting social inclusion, reduction of poverty and economic development in rural areas has become a priority in the development of EU rural areas. These demands are implemented as part of the LEADER programme, while the Local Action Groups (LAGs) have become the institution involved in the animation of disadvantaged groups (Guzal-Dec, ZwolinskaLigaj, 2017a; Guzal-Dec, Zwolinska-Ligaj, 2017b). 
In the context of the implementation of the smart development concept with regard to rural territorial units, it should be remembered that territorial units located in peripheral regions do not have the same access to resources as growth centres or communes directly adjacent to them (Bilbao-Osorio, Rodriguez-Pose, 2004 ; McCann, Ortega-Argiles, 2015, Naldi 2015). However, in case of these regions, there are some possibilities of launching smart factors in the process of their development. Increasingly, the literature emphasizes the importance of services related to local, place-based amenities and entrepreneurship in the context of rural development (Rappaport, 2009).

\section{Operationalisation of the social dimension of the smart villages concept}

Based on a critical review of the literature, including proposals from Szczech-Pietkiewicz (2015), Obrebalski (2016) and Hajduk (2016), variables describing the social dimension of the concept of intelligent development were distinguished ${ }^{1}$. The construction of a set of indicators enabling operationalisation of the smart concept in its social dimension was associated with the disclosure of difficulties such as the reference to national conditions and realities and the simultaneous consideration of the specificity of rural settlement units and the limited access to public statistics, especially with regard to soft factors/variables.

In the process of defining a set of indicators describing the social dimension of smart development, the following assumptions were adopted: data availability for rural and rural-urban communes in Lublin Province, substantive usefulness, acceptable level of variability (value of the coefficient of variation above $10 \%$ ) and the degree of correlating with each other (value of the correlation coefficient below 0.7 ).

Ultimately, the study used 11 variables that meet the above conditions and characterise the quality of life, human capital and social capital. Variables $X_{1}-X_{3}$ refer to the quality of life, $X_{4}-X_{8}-$ describe human capital, while $X_{9}-X_{11}$ - refer to social capital:

$X_{1}$ percentage of dwellings in a commune within Next Generation Access (NGA) in the total number of dwellings in the commune;

$X_{2}$ number of specialist laboratories per 10,000 inhabitants;

$X_{3}$ number of entities providing health care and social assistance per 100 inhabitants;

$\mathrm{X}_{4}$ the gross schooling rate for primary schools;

$X_{5}$ number of members of IT associations per 1,000 inhabitants;

$X_{6}$ percentage of additional foreign language learning in primary schools;

$\mathrm{X}_{7}$ the percentage of town councillors representing a vocational group of specialists in the total number of town councillors;

$\mathrm{X}_{8}$ the percentage of town councillors with higher education qualifications in the total number of town councillors;

$\mathrm{X}_{9}$ number of foundations, associations and social organisations per 1,000 inhabitants;

$\mathrm{X}_{10}$ the value of expenditures implemented within municipal budget as part of the Solecki Fund $^{2}$ per 1 inhabitant;

$\mathrm{X}_{11}$ number of Universities of the Third Age (UTA) members per 1,000 inhabitants.

${ }^{1}$ The concept of comprehensive measurement of intelligent development of rural and urban-rural communes based on 24 indicators is presented in the work by Magdalena Zwolinska-Ligaj, Danuta Guzal-Dec, Mieczyslaw Adamowicz, Intelligent development as a concept for development of rural and urban-rural territorial units - an example of a peripheral region, manuscript 2018.

2 Funds separated from the municipal budget, guaranteed for the implementation of projects aimed at improving the lives of residents.

${ }^{1}$ Corresponding author. .Tel.:: +48603867576; fax:+ 48833449950.E-mail address: danuta_guzal-dec@wp.pl.ORCID:0000-0002-2143-1649 300

${ }^{2}$ Corresponding author. Tel.: +48606374521; fax: +48833449950. E-mail address: m.zwolinska-ligaj@dydaktyka.pswbp.pl ORCID:0000-00016770-709) 
The "quality of life" was described by variables characterising the availability of modern information exchange infrastructure, opportunities to develop knowledge and technical and language skills in specialist laboratories available in the communes, such as polytechnic, computer and foreign language learning and the availability of entities providing health and physiotherapeutic care and social assistance. In the study, "human capital" was described with variables referring to the quality of primary education, the degree of involvement of the population in the development of IT competencies and the level and degree of education and professional specialization of town councillors. To characterize the area of "social capital", measures related to social activity within non-governmental organizations, including the activities of seniors as part of the Universities of the Third Age initiatives, as well as the involvement of local self-government representatives in the municipality issues expressed by the level of the Solecki Fund were used.

The temporal scope of the data acquired for the construction of $\mathrm{X}_{1}-\mathrm{X}_{10}$ and $\mathrm{X}_{11}$ variables covered the year 2016, while for the $X_{10}$ indicator, the period 2014-2016 was taken into account. The indicators were built based on the resources of the Local Data Bank of the Central Statistical Office $\left(\mathrm{X}_{2}-\mathrm{X}_{11}\right)$ and data of the Office of Electronic Communications. The values of the above variables have been set for 193 communes of Lublin Province, including 167 rural and 26 urbanrural communes. In order to organize the analysed territorial units in terms of the level of development criterion of the social dimension of the smart village concept, the zero uniformisation method was applied (Kukula, 2014). The formula of quotient conversion was used for normalization. Diagnostic variables were normalized according to the following formula (Kukula, 2014):

$$
z_{i j}=\frac{x_{i j}-\min _{i} x_{i j}}{\max _{i} x_{i j}-\min _{i} x_{i j}}
$$

After normalizing the variables $(j=1, \ldots, m)$, the value of the synthetic variable Qi characterizing each object (commune) ( $r$ objects) was determined on the basis of the values of the $Z$ matrix elements due to the status of the advancement of the smart villages concept (Kukula ,2014):

$$
Q_{i}=\frac{1}{m} \sum_{j=1}^{m} z_{i j} \quad(i=1, \ldots, r)
$$

The last activity was the division of the collectivity of communes into 3 groups taking into account the state of advancement of the studied phenomenon - low, medium and high (Kukula, 2014). For this purpose, the distribution of the synthetic variable was determined according to the formula:

$$
R\left(Q_{i}\right)=\max _{i} Q_{i}-\min _{i} Q_{i}
$$

and the partition parameter $\mathrm{k}$ was determined according to the formula:

$$
k=\frac{1}{3} R\left(Q_{i}\right)
$$

Three groups of territorial units were separated on the basis of the following procedures:

3) a group with a high level of complex phenomenon:

$$
Q_{i} \in\left[\max _{i} Q_{i}-k \max _{i} Q_{i}\right]
$$

4) group with an average level of complex phenomenon: 


$$
Q_{i} \in\left[\max _{i} Q_{i}-2 k, \max _{i} Q_{i}-k\right)
$$

5) a group with a low level of complex phenomenon:

$$
Q_{i} \in\left[\max _{i} Q_{i}-3 k, \max _{i} Q_{i}-2 k\right)
$$

\section{Characteristics of the level of development of social dimension of smart development of rural areas in Lublin Province}

The lowest value of the variable of synthetic indicator of the level of smart development was 0.564 (Abramow commune), and the highest - 3.887 (recorded in case of the Rossosz commune). Therefore, the distribution of the synthetic variable reached the value of 3.323 , and the partition parameter $\mathrm{k}=1.108$. On their basis, the intervals were determined, on the basis of which the examined territorial units were qualified to one of the three classes of the level of smart development in the social dimension (Table 1 ).

Structure of communes in Lublin Province in terms of the number of

Table 1 territorial units representing separate categories of the synthetic indicator

\begin{tabular}{|c|c|c|c|c|c|c|c|}
\hline \multirow{2}{*}{$\begin{array}{c}\text { Category of the } \\
\text { social dimension } \\
\text { of smart } \\
\text { development }\end{array}$} & \multirow{2}{*}{$\begin{array}{l}\text { The range of values } \\
\text { of the synthetic } \\
\text { indicator Qs }\end{array}$} & \multicolumn{3}{|c|}{$\begin{array}{c}\text { Number of } \\
\text { communes per category }\end{array}$} & \multicolumn{3}{|c|}{$\begin{array}{c}\text { Share of communes in the } \\
\text { category }(\%)\end{array}$} \\
\hline & & Total & Rural & $\begin{array}{l}\text { Urban- } \\
\text { rural }\end{array}$ & Total & Rural & $\begin{array}{l}\text { Urban- } \\
\text { rural }\end{array}$ \\
\hline High & Qs $\in<2.779 ; 3.887>$ & 16 & 14 & 2 & 8.29 & 8.38 & 7.69 \\
\hline Average & Qs $\in<1.672 ; 2.779)$ & 96 & 82 & 14 & 49.74 & 49.10 & 53.85 \\
\hline Low & $Q s \in<0.564 ; 1.672)$ & 81 & 71 & 10 & 41.97 & 42.52 & 38.46 \\
\hline & Total & 193 & 167 & 26 & 100.00 & 100.00 & 100.00 \\
\hline
\end{tabular}
level of the social dimension of smart development by commune type

Source: authors' study based on the Local Data Bank of the Central Statistical Office and the Office of Electronic Communications

The structure of the analysed municipalities of Lublin Province, in terms of the number of units representing the three distinct types of synthetic indicators, was characterized by a significant share of units classified into the low and average categories. Units representing a high level of intelligent development accounted for only $8.29 \%$ of all rural and urban-rural communes in the region. One characteristic aspect is that only a slight number of urban-rural communes found themselves in the high-level category of the studied phenomenon. The structure similarity test was applied by means of the indicator of the similarity of structures defined by the formula:

$$
\omega_{p}=\sum_{i=1}^{k} \min \left(W_{s k 1 i}, W_{s k 21}\right)
$$

for $0<\omega_{\mathrm{p}} \leq 1 ; W_{s k 1 i}, W_{s k 21}-$ index of the structure of $\mathrm{i}$-th feature in the population 1 and 2 .

Pointed to a very large similarity $\omega_{\mathrm{p}}=0.95$. By applying the non-parametric Mann-Whitney $\mathrm{U}$ test, it has been demonstrated that there is no statistical significance of differences between the level of the synthetic index of the social dimension of smart development in rural and urban-rural communes $(U=2103, p=0.799)$. The average level of the synthetic indicator of the social dimension of smart development in rural communes amounted to 1.893 , with a standard deviation of 0.602 , and in urban-rural communes it was 1.827, with a standard deviation of 0.635 . The first hypothesis posed in the work was a subject to a negative verification, namely that the structure of urban-rural

${ }^{1}$ Corresponding author. .Tel.:: +48603867576; fax:+48833449950.E-mail address: danuta_guzal-dec@wp.pl .0RCID:0000-0002-2143-1649 302 ${ }^{2}$ Corresponding author. Tel.: +48606374521; fax: +48833449950. E-mail address: m.zwolinska-ligaj@dydaktyka.pswbp.pl ORCID:0000-00016770-709) 
communes differs from the structure of rural communes due to the level of the social dimension of smart development, and that the urban-rural communes show a higher level of the indicator.

Taking into account the level of development of the social dimension of smart development, the spatial distribution of the surveyed territorial units is characterized by the presence of few, unevenly distributed aggregations of units with a high level of smart development. They are not compact blocks, yet they start to form some potential clusters. There were only two clusters in which more than two units with the highest potential were in the immediate position.

The units at a high level of smart development are located in the north-eastern part of the region. Most often, they do not occur in close proximity to larger urban centres (Figure 1).

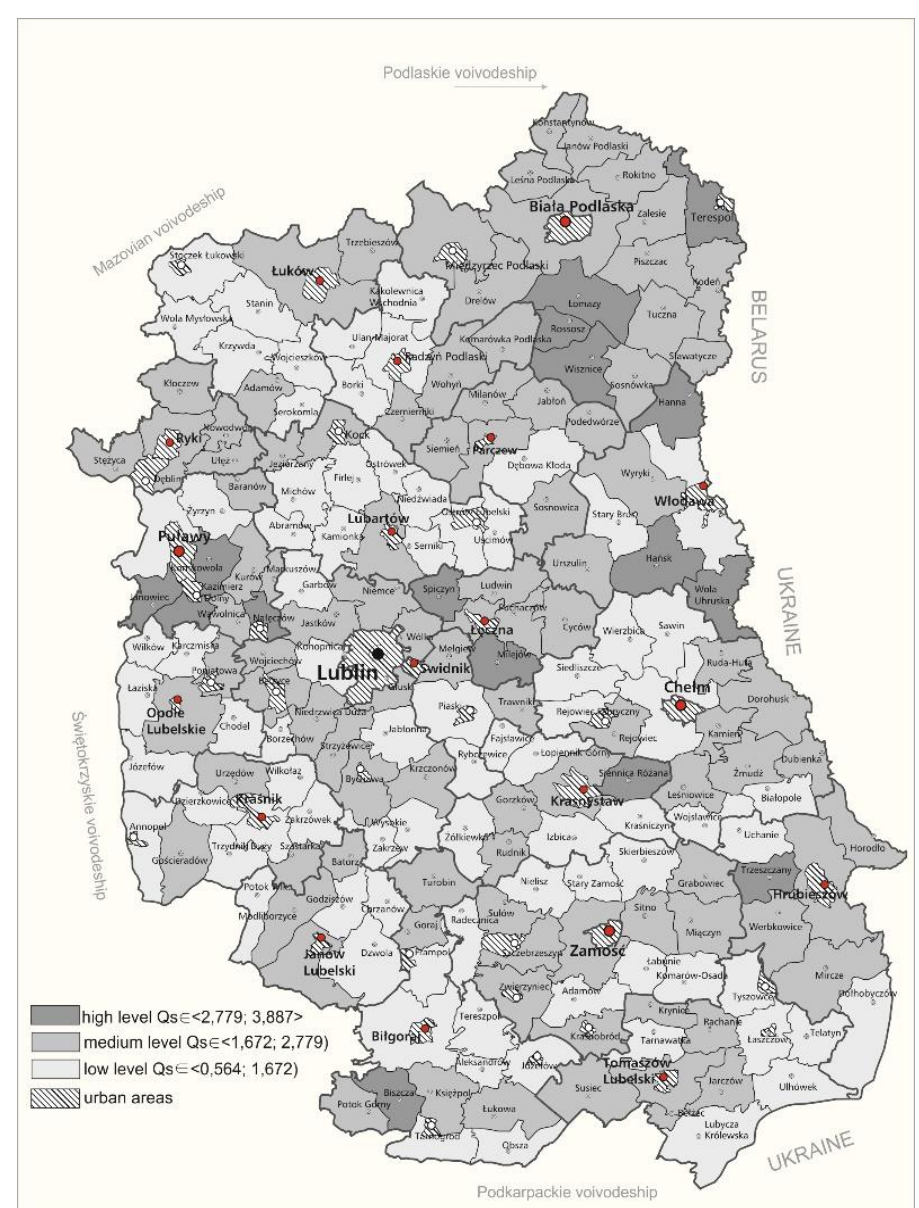

Source: authors' study based on the Local Data Bank of the Central Statistical Office and the Office of Electronic Communications

Fig. 1. Rural and urban-rural communes in Lublin Province according to the synthetic indicator of the social dimension of smart development

The highest levels of the synthetic indicator of the social dimension of smart development were recorded in case of the city of Pulawy - an urban centre with a developed industry and a scientific and research base, located near the border of the most economically strong region in the country (Mazowieckie Provine), areas of the Leczna district with rich hard coal deposits, characterized by good communication with Lublin - the capital of the region, and the areas of Bialski district, largely of an agricultural nature, developing modern and alternative sources of energy and high potential for social activity.

In addition, the emerging impact of selected Local Action Groups (LAGs) in the region can be noticed, including Bialskopodlaska LAG that groups the communes of the Bialski district; Zielony Pierscien LAG, which associates the municipalities of Pulawy, or Lepsza Przyszlosc Ziemi ryckiej

${ }^{1}$ Corresponding author. .Tel.:: +48603867576; fax:+ 48833449950.E-mail address: danuta_guzal-dec@wp.pl.0RCID:0000-0002-2143-1649 303 ${ }^{2}$ Corresponding author. Tel.: +48606374521; fax: +48833449950. E-mail address: m.zwolinska-ligaj@dydaktyka.pswbp.pl ORCID:0000-00016770-709) 
LAG. The potential impact of LAGs on the development of human and social capital requires further in-depth research.

Analysis of the spatial structure of communes with different levels of the social dimension of smart development indicates a low level of influence of former regional cities in which currently higher vocational universities are located (Chelm, Zamosc) and insufficient level of influence of the cultural and economic centre - the capital of Lublin Province.

The abovementioned outcomes indicate that the second research hypothesis can be verified negatively, namely the assumption that a spatial concentration of units with the highest level of the indicator is located in the immediate vicinity of the largest urban centres in the region.

\section{Conclusions, proposals, recommendations}

1) Similarly to the smart city concept, the dimensions of people/society and the quality of life, as well as activities aimed at building a civic society and social inclusion are equally important in the smart village concept. Since peripheral regions are in particular sparsely populated by the creative class, and it is difficult to attract the creative class of people, it should be noted that investing in and promoting smart people becomes an indispensable catalyst for implementing the smart villages concept.

2) The studied peripheral region, like other units of this type, exhibits a low potential of social component in the scope of the smart development; the rural and urban-rural communes of the region are mostly characterized by a low level in terms of the analysed variables describing the quality of life, human and social capital. A higher potential of urban-rural units compared to rural communes was not noticed. The social smart potential is strongly dispersed. There is also no positive impact on the rural potential by the major urban centres in the region. Certain aggregations are distinguished within the framework of selected LAGs operating in the region.

3) Strengthening the LAG's potential as part of the CLLD initiative seems to be a desirable direction to support the endogenous potential of rural territorial units enabling implementation of the smart villages concept. As part of the LAG's activity, projects promoting the development of social capital should be favoured, alongside with educational initiatives including in particular: distance/ e-learning, learning by doing, and long-time learning.

4) There is also a need to strengthen the interaction links between regional universities and the local self-governments of surrounding communes; it seems that universities can fulfil the important role of local and sub-regional centres stimulating inter-sectoral cooperation, including cooperation with local governments; cooperation in the dimension of education, culture and social activation, and cooperation that aims at strengthening human capital and leads to the manifestation of social innovations in the above dimensions. Another possible area of cooperation are initiatives with entities from the economic sector, which will result in innovations that affect the quality of life.

\section{Acknowledgement}

The paper was prepared under project no KEiZ / ZZ-1 entitled: "The concept of intelligent development of villages, settlements, cities and regions" implemented as part of statutory research of Pope John Paul II State School of Higher Education in Biala Podlaska, Faculty of Economics and Technical Sciences. 


\section{Bibliography}

1. Albino, V., Berardi, U., Dangelico, R.M. (2015). Smart Cities: Definitions, Dimensions, Performance, and Initiatives. Journal of Urban Technology, Volume 22, Issue 1, pp. 3-21.

2. Bartlett L. (2005). Smart City: Social Entrepreneurship and Community Engagement in a Rural Regional City. In Proceedings of the International Conference on Engaging Communities. Retrieved: https://publications.qld.gov.au/storage/f/2014-01-31T06 \%3A25 \%3A48.168Z/bartlet-leo-final.pdf Access: 01.01.2018.

3. Berardi, U. (2013). Sustainability Assessments of Urban Communities through Rating Systems. Environment, Development and Sustainability, Volume 15, Issue 6, pp. 1573-1591.

4. Bilbao-Osorio, B., Rodríguez-Pose, A. (2004). From R\&D to Innovation and Economic Growth in the EU. Growth Change, Volume 35, Issue 4, pp. 434-455.

5. Chourabi, H., Nam T., Walker, S., Gil-Garcia J.R., Mellouli S., Nahon K., Pardo T.A., Scholl H.J. (2012). Understanding Smart Cities: an Integrative Framework, Proceeding of HICSS, pp. 2289-2297.

6. Cocchia, A. (2014). Smart and Digital City: a Systematic Literature Review. In R. P. Dameri, C. Sabroux (Eds.). Smart city: How to Create Public and Economic Value with High Technology in Urban Space. Switzerland: Springer International Publishing.

7. Cork 2.0 Declaration 2016, A Better Life in Rural Areas. Retrieved: https://ec.europa.eu/agriculture/sites/agriculture/files/events/2016/rural-development/cork-declaration-20_en.pdf Access 01.01.2018.

8. Eger, J. M. (2009). Smart Growth, Smart Cities, and the Crisis at the Pump a Worldwide Phenomenon. IWays, Volume 32, Issue, pp. 47-53.

9. Eurostat, 2016. Retrieved: http://ec.europa.eu/eurostat Access 01.01.2018.

10. Giffinger, R., Fertner, C., Kramar, H., Kalasek, R., Pichler-Milanovi, N., Meijers, E. (2007). Smart Cities: Ranking of European Medium-Sized Cities. Vienna, Austria: Centre of Regional Science (SRF), Vienna University of Technology. Retrieved: http://www.smart-cities.eu/download/smart_cities_final_report.pdf Access 01.01.2018.

11. Gil-Garcia, J. R., Pardo, T.A., Nam, T. (2015). What Makes a City Smart? Identifying Core Components and Proposing an Integrative and Comprehensive Conceptualization. Information Polity. Volume 20, pp. 61-87.

12. Guzal-Dec, D., Zwolinska-Ligaj M. (2017a). Lokalne grupy dzialania na rzecz wlaczenia spolecznego w wojewodztwie lubelskim (Local Action Groups for Social Inclusion in Lublin Province). SERiA, Volume XIX, Issue 3.

13. Guzal-Dec, D., Zwolinska-Ligaj M. (2017b). Local Action Groups as New Organisations in Rural Development an Exapmle of the Lublin Region (Poland). Proceedings of the 2017 International Conference "ECONOMIC SCIENCE FOR RURAL DEVELOPMENT" No 44 Jelgava, LLU ESAF, 27-28 April 2017, pp. 58-68.

14. Hajduk, S. (2016). The Concept of a Smart City in Urban Management. Business, Management and Education, Volume 14, Issue 1, pp. 34-49.

15. Hollands, R.G. (2008). Will the Real Smart City Please Stand Up? City: Analysis of Urban Trends, Culture, Theory, Policy, Action, Volume 12, Issue 3, pp. 303-320.

16. Innovation and Digitisation Key for Strong and Sustainable Rural Areas, News 12 October Brussels, Belgium, Agriculture and Rural Development. Retrieved: https://ec.europa.eu/info/news/innovation-and-digitisationkey-strong-and-sustainable-rural-areas_en Access 01.01.2018

17. Isserman, A.M., Feser E., Warren D.E. (2009). Why Some Rural Places Prosper and Others Do Not. International Regional Science Review, Volume 32, Issue 3, pp. 300-342.

18. Komninos, N. (2006). The Architecture of Intelligent Cities Integrating Human, Collective, and Artificial Intelligence to Enhance Knowledge and Innovation. Proceedings of the 2 International Conference on Intelligent Environments, Institution of Engineering and Technology, Athens, 5-6 July 2006, p.13. Retrieved: http://www.urenio.org/wp-content/uploads/2008/11/2006-The-Architecture-of-Intel-Cities-IE06.pdf Access: 01.01.2018.

19. Krueger, A.O. (1993). Virtuous and Vicious Circles in Economic Development. American Economic Review (AEA Papers and Proceedings), Volume 83, Issue 2, pp. 351-355.

20. Kukula, K. (2014). Regionalne zroznicowanie stopnia zanieczyszczenia srodowiska w Polsce a gospodarka odpadami (Regional Diversity of the Degree of Environmental Pollution in Poland and Waste Management). In: Piekutowska A., Rollnik-Sadowska E. eds. Przedsiebiorczosc i Zarzadzanie, Volume XV, Issue 8, Part I, Wybrane problemy zarzadzania rozwojem regionalnym (Selected Problems of Managing Regional Development).

21. Lombardi, P., Giordano, S., Farouh, H., Yousef, W. (2012). Modelling the Smart City performance. Innovation - The European Journal of Social Science Research, Volume 25, Issue 2, pp. 137-149.

22. Mahizhnan, A. (1999). Smart Cities: The Singapore Case. Cities, Volume 16, Issue 1, pp. 13-18.

23. McCann, P., Ortega-Argiles, R. (2015). Smart Specialization, Regional Growth and Applications to European Union Cohesion Policy. Regional Studies, Volume 49, Issue 8, pp. 1291-1302.

24. Miszczuk, A. (2013). Uwarunkowania peryferyjnosci regionu przygranicznego. (Determinants of the Peripherality of the Border Region). Lublin: Norbertinum 2015, p.113.

25. Monfaredzadeh T., Krueger R. (2015).Investigating Social Factors of Sustainability in a Smart City. International Conference on Sustainable Design, Engineering and Construction. Procedia Engineering, Volume 118, pp. $1112-1118$

${ }^{1}$ Corresponding author. .Tel.::+48603867576; fax:+48833449950.E-mail address: danuta_guzal-dec@wp.pl .ORCID:0000-0002-2143-1649 305 ${ }^{2}$ Corresponding author. Tel.: +48606374521; fax: +48833449950. E-mail address: m.zwolinska-ligaj@dydaktyka.pswbp.pl ORCID:0000-00016770-709) 
26. Monzon, A. (2015). Smart Cities Concept and Challenges: Bases for the Assessment of Smart City Projects. Retrieved: http://ieeexplore. ieee.org/stamp/stamp.jsp?tp=\&arnumber $=7297938$ Access: 01.01.2018.

27. Naldi, L., Nilsson, P., Westlund, H., Wixe, S. (2015). What Is Smart Rural Development? Journal of Rural Studies, Volume 40, pp. 90-101.

28. Nam, T., Pardo, T.A. (2011). Conceptualizing Smart City with Dimensions of Technology, People, and Institutions, Proceedings of the 12 Conference on Digital Government Research, College Park, MD, June 12$15,2011$.

29. Neirotti, P., De Marco, A., Cagliano, A., Mangano, G., Scorrano, F. (2014). Current Trends in Smart Cities Initiatives: Some Stylised Facts. Cities, Volume 38, Issue, pp. 25-36.

30. Nurzynska, I. (2016). Przyczyny i przejawy peryferyjnosci obszarow wiejskich w Polsce (Causes and Manifestations of the Peripherality of Rural Areas in Poland). Wies i Rolnictwo, Volume 171, Issue 2, pp. 123-139.

31. Obrebalski, M. (2016). Specjalizacja i inteligencja miasta - identyfikacja, pomiar i ocena (City Specialisation and Intelligence - Identification, Measurement and Evaluation). Studia KPZK, Volume 170, pp. 112-124.

32. Olechnicka, A., Smetkowski, M. (2007). Wplyw technologii teleinformacyjnych na rozwoj regionu peryferyjnego (na przykladzie wojewodztwa podlaskiego). (Influence of Teleinformation Technologies on the Development of the Peripheral Region as Illustrated by the Case of Podlaskie Provine). Studia Regionalne $i$ Lokalne, 4 (30), 48-65.

33. Rappaport, J. (2009). The Increasing Importance of Quality of Life. Journal of Economic Geography, Volume 9, Issue 6, pp. 779-804.

34. Shapiro, J.M. (2006). Smart Cities: Quality of Life, Productivity, and the Growth Effects of Human Capital. Review of Economics \& Statistics, Volume 88, Issue 2, pp. 324-335.

35. Szczech-Pietkiewicz, E. (2015). Smart city - proba definicji i pomiaru (Smart City - an Attempt to Define and Measure). Prace Naukowe Uniwersytetu Ekonomicznego we Wroclawiu/ Research Papers of Wroclaw University of Economics, Volume 391, pp. 71-82.

36. Thuzar, M. (2011). Urbanization in South East Asia: Developing Smart Cities for the Future? Regional Outlook, pp. 96-100.

37. Villages and Small Towns as Catalysts for Rural Development, Opinion Prepared by European Economic and Social Committee (EESC)18.10 2017 Retrieved: http://www.eesc.europa.eu/en/our-work/opinionsinformation-reports/opinions/villages-and-small-towns-catalysts-rural-development Access 01.01.2018.

38. Zwolinska-Ligaj, M., Guzal-Dec, D., Adamowicz, M. (2018). Inteligentny rozwoj jako koncepcja rozwoju wiejskich i miejsko-wiejskich jednostek terytorialnych - przyklad regionu peryferyjnego, maszynopis (Smart Development as a Concept for the Development of Rural and Urban-Rural Territorial Units - an Example of the Peripheral Region, Manuscript)

${ }^{1}$ Corresponding author. .Tel.:: +48603867576; fax:+48833449950.E-mail address: danuta guzal-dec@wp.pl .ORCID:0000-0002-2143-1649 ${ }^{2}$ Corresponding author. Tel.: +48606374521; fax: +48833449950. E-mail address: m.zwolinska-ligaj@dydaktyka.pswbp.pl ORCID:0000-00016770-709) 